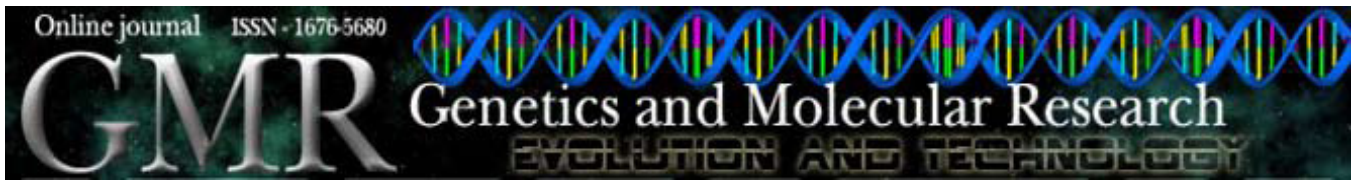

\title{
Cloning, partial sequence, and single-nucleotide polymorphism of the ryanodine receptor gene of the Pacific white shrimp Litopenaeus vannamei (Penaeidae)
}

\author{
X.H. Chen, D.G. Zeng and N. Ma \\ Biotechnology Laboratory, Fisheries Research Institute of Guangxi, \\ Nanning, China \\ Corresponding author: D.G. Zeng \\ E-mail: zengdigang@gmail.com
}

Genet. Mol. Res. 9 (4): 2406-2411 (2010)

Received August 27, 2010

Accepted September 26, 2010

Published December 14, 2010

DOI 10.4238/vol9-4gmr976

\begin{abstract}
Ryanodine receptor/calcium release channel is a large protein that plays an essential role in muscle contraction; mutations in the ryanodine receptor gene affect sensitivity to stress. As a first step towards investigating the relationship between the ryanodine receptor and shrimp cramped muscle syndrome, we cloned, partially sequenced, and examined single-nucleotide polymorphisms (SNPs) of the ryanodine receptor gene of the Pacific white shrimp (Litopenaeus vannamei). The nucleotide sequence of a $15.06-\mathrm{kb}$ L. vannamei genomic DNA segment containing a partial ryanodine receptor gene sequence was determined (deposited in GenBank nucleotide database: HM367069). Direct sequencing of PCR-amplified ryanodine receptor exons with their intron-flanking regions in 10 cramped muscle syndrome shrimp and 10 healthy shrimp, revealed seven SNPs. Five of them $(1713 \mathrm{~A} / \mathrm{G}, 1749 \mathrm{~T} / \mathrm{C}, 1755 \mathrm{~T} / \mathrm{C}, 3965 \mathrm{G} / \mathrm{A}$, and $8737 \mathrm{C} / \mathrm{T})$ are located in exons; however, they appear to be neutral (synonymous), since they do not alter the encoded amino acid. The other SNPs $(1553 \mathrm{C} / \mathrm{T}$ and $13337 \mathrm{~A} / \mathrm{G})$ are in introns. The SNPs identified in the ryanodine receptor gene could be useful for association studies aimed
\end{abstract}


at determining the physiological role of the ryanodine receptor in cramped muscle syndrome of shrimp.

Key words: Litopenaeus vannamei; Ryanodine receptor; Cloning; Single-nucleotide polymorphism

\section{INTRODUCTION}

Calcium is an important intracellular signaling molecule, and altered calcium channel function can cause widespread cellular changes. Genetic mutations in ryanodine receptor/ calcium channels that cause what appear to be trivial alterations of calcium currents in vitro can result in serious diseases in muscles and the nervous system (Lorenzon and Beam, 2000).

In mammalian (human, mouse, rabbit, pig, etc.), more than 30 missense mutations that lead to the susceptibility to stress reaction, such as malignant hyperthermia (MH) (Loke and MacLennan, 1998), were found in the coding sequence (Jurkat-Rott et al., 2000). In humans, $22 \mathrm{MH}$ mutations have been identified at 20 different amino acid residues in the ryanodine receptor-coding regions (Jurkat-Rott et al., 2000). In swines, MH is a pharmacogenetic disease that affects calcium regulation in muscle and results in sudden death and (or) in PSE (pale, soft, and exudative) meat (Mitchel and Heffron, 1982). Recently, a C to T transition at nucleotide 1843 in the coding sequence of skeletal muscle ryanodine receptor was associated with MH susceptibility (Fujii et al., 1991). Eliminating mutation genotypes of skeletal ryanodine receptor has been widely used in the pig breeding (Mitchel and Heffron, 1982).

Ryanodine receptor has been identified in various mammalian and nonmammalian vertebrate animals. Homologs to vertebrate ryanodine receptor in invertebrates, including Drosophila melanogaster (Takeshima et al., 1994; Hoskins et al., 2007), Caenorhabditis elegans (Sakube et al., 1997), and Hemicentrotus pulcherrimus (Shiwa et al., 2002), have also been cloned and sequenced. The pacific white shrimp, Litopenaeus vannamei (Boone, 1931), has become the leading farm species in the western hemisphere (Valles-Jimenez et al., 2004). In recent years, cramped muscle syndrome (CMS) (Lightner, 1988) has caused economic losses to the shrimp industry. CMS of shrimp has also been called "cramped tail", "body cramp", and "bent tail". Although the complete etiology of CMS has not been definitively ascertained, it was hypothesized to be a stress reaction in susceptible shrimp, caused by physiological or nutritional factors that are enhanced by physical or environmental stressors (John, 1992). Therefore, analysis of the ryanodine receptor gene may be helpful to understand the cause of shrimp CMS.

\section{MATERIAL AND METHODS}

A library was constructed by the L. vannamei DNA size fractionation, clean-up of the DNAs, and subsequent ligation into a fosmid vector, pCC1FOS ${ }^{\mathrm{TM}}$ Vector (Epicentre, USA). The ligation mixture was then packaged into lambda phages using MaxPlax Lambda Packaging Extracts (Epicentre). The packaged library was transduced into Escherichia coli $\mathrm{EPI} 300-\mathrm{T} 1^{\mathrm{R}}$, and E. coli transformants were selected on LB agar supplemented with chloramphenicol. The presence of recombinant plasmids and the polymorphism of the insert DNA were examined by agarose gel electrophoresis of an Not I digestion of 
the purified plasmids from randomly selected $E$. coli transformants. The library clones were stored in 96-well plates. To isolate the ryanodine receptor gene, the library was screened by polymerase chain reaction (PCR) analysis. The PCR primer pairs were designed according to the EST (GenBank ID: FE180577) (De-la-Vega et al., 2008) from $L$. vanname $i$ and are homologous to ryanodine receptor gene from D. melanogaster (GenBank ID: NM_057645) (Hoskins et al., 2007): F:5'-GTGAAGAAGAAGGTCCGTGAGAAGT-3'; R:5'-GAAAGGTATCCGATGATGCCCGTTG-3'. The PCR amplification mixtures of $25 \mu \mathrm{L}$ contained the following: $100 \mathrm{ng}$ genomic DNA, primers $(0.5 \mu \mathrm{M}$ each), $1.5 \mathrm{mM} \mathrm{MgCl}, 0.2 \mathrm{mM}$ dNTPs, 1X PCR buffer, and 1 U Taq DNA polymerase (Promega, USA). The cycling conditions were 5 min denaturation at $94^{\circ} \mathrm{C}$, followed by 35 cycles of $94^{\circ} \mathrm{C}$ for $30 \mathrm{~s}, 57^{\circ} \mathrm{C}$ for $30 \mathrm{~s}, 72^{\circ} \mathrm{C}$ for $1 \mathrm{~min}$, and a final extension at $72^{\circ} \mathrm{C}$ for $5 \mathrm{~min}$. The selected unique fosmid clones were purified, partially digested with Sau3AI to have 1-4-kb size DNA, and ligated into a linearized pUC118 vector (Promega) to generate the secondary shotgun library. Sequence reactions were carried out using the M13-M3 and M13-RV primers. Gaps were covered by primer walking. The sequence data were assembled by CodonCode Aligner V3.0. For the determination of putative transmembrane regions, the exon and intron were predicted using the GENSCAN server (http://genes.mit.edu/GENSCAN.html). The deduced amino acid sequence of L. vannamei ryanodine receptor was compared with the corresponding region of $D$. melanogaster ryanodine receptor (GenBank ID: NM_057645) (Hoskins et al., 2007) using the CLUSTAL W program (Higgins and Sharp, 1988).

The population of L. vannamei was a specific pathogen-free stock originating from the High Health Aquaculture (Kona, Hawaii, USA). Ten shrimps with cramped muscle syndrome and 10 healthy shrimps were collected from the pond. Genomic DNA was extracted from each shrimp muscle using the Genome DNA Extraction Kit (Promega). The coding sequences of the ryanodine receptor genomic DNA were amplified in 20 using 11 pairs of primers (Table 1). The PCR amplification mixtures of $25 \mu \mathrm{L}$ contained the following: $100 \mathrm{ng}$ genomic DNA, primers $(0.5 \mu \mathrm{M}$ each), $1.5 \mathrm{mM} \mathrm{MgCl}, 0.2$ $\mathrm{mM}$ dNTPs, 1X PCR buffer, and 1 unit Taq DNA polymerase (Promega, USA). The cycling conditions were 5 min denaturation at $94^{\circ} \mathrm{C}$, followed by 35 cycles of $94^{\circ} \mathrm{C}$ for $30 \mathrm{~s}, 57^{\circ} \mathrm{C}$ for $30 \mathrm{~s}, 72^{\circ} \mathrm{C}$ for $1 \mathrm{~min}$, and a final extension at $72^{\circ} \mathrm{C}$ for $5 \mathrm{~min}$. The PCR products were purified and double strands sequenced by ABI377 automated DNA sequencer (performed by Tiangen Company, Bejing). DNA comparison were performed using the DNAMAN software program (Zemann et al., 2006).

\begin{tabular}{|c|c|c|c|c|c|}
\hline Primers & Forward sequence & Reverse sequence & Position of 5' nucleotide & Product size (bp) & Exons covered \\
\hline P1 & ctgagatgaaagatagggtcca & gaaaacgcaaaatcacataaag & $299-723$ & 425 & 1 \\
\hline P2 & atagcaacagaaagacactcg & cccctaaaaggaactcaaa & $1575-2303$ & 729 & $2-3$ \\
\hline P3 & ggtcctgttgatcctctaa & aagctctttcacgtcctaa & 2533-3002 & 459 & 4 \\
\hline P4 & ggtttgtttcctgttcctt & agtatcctaactgeccetc & $3735-4041$ & 307 & 5 \\
\hline P5 & taggtttgtttcctgttcc & atttcccataatcgtgtct & $3733-4352$ & 620 & $5-6$ \\
\hline P6 & ttagcaaagtcagtagaaagg & actcatacagtagataccaaaga & $7627-8205$ & 579 & 7 \\
\hline P7 & tggcacatctgtaactcct & ttctcettgtctccetctg & $8555-9268$ & 714 & $8-9$ \\
\hline P8 & tgaccaccactcactcca & gaaagcagaaactcaaaagac & $10378-11161$ & 784 & $9-10$ \\
\hline P9 & ccattagtggtgecgtagt & aaggcgatgacagtgtagc & $11254-11683$ & 430 & $11-12$ \\
\hline P10 & gtatccagattcgttgtcc & tgtttacggattttgtgag & $11912-12699$ & 788 & 13 \\
\hline P11 & ctcacaaaatccgtaaaca & caacgaaacttctaacagc & $12681-13397$ & 717 & $14-15$ \\
\hline
\end{tabular}




\section{RESULTS}

A fosmid genomic library was constructed for L. vannamei. After screening the fosmid library, a positive clone was obtained and subjected to shotgun sequencing. A nucleotide sequence (the sequence has been deposited in GenBank nucleotide database: HM367069) of a 15.06-kb genomic DNA segment containing partial ryanodine receptor gene has been determined. The sequence contains 15 exons encoding 1237 amino acids. The deduced amino acid sequence of the L. vannamei ryanodine receptor is $64.8 \%$ identical with the corresponding region of $D$. melanogaster ryanodine receptor amino acid sequence (Figure 1). The results indicated that the deduced amino acid sequence of $L$. vannamei ryanodine receptor is highly similar to amino-terminal sequences of the $D$. melanogaster ryanodine receptor.

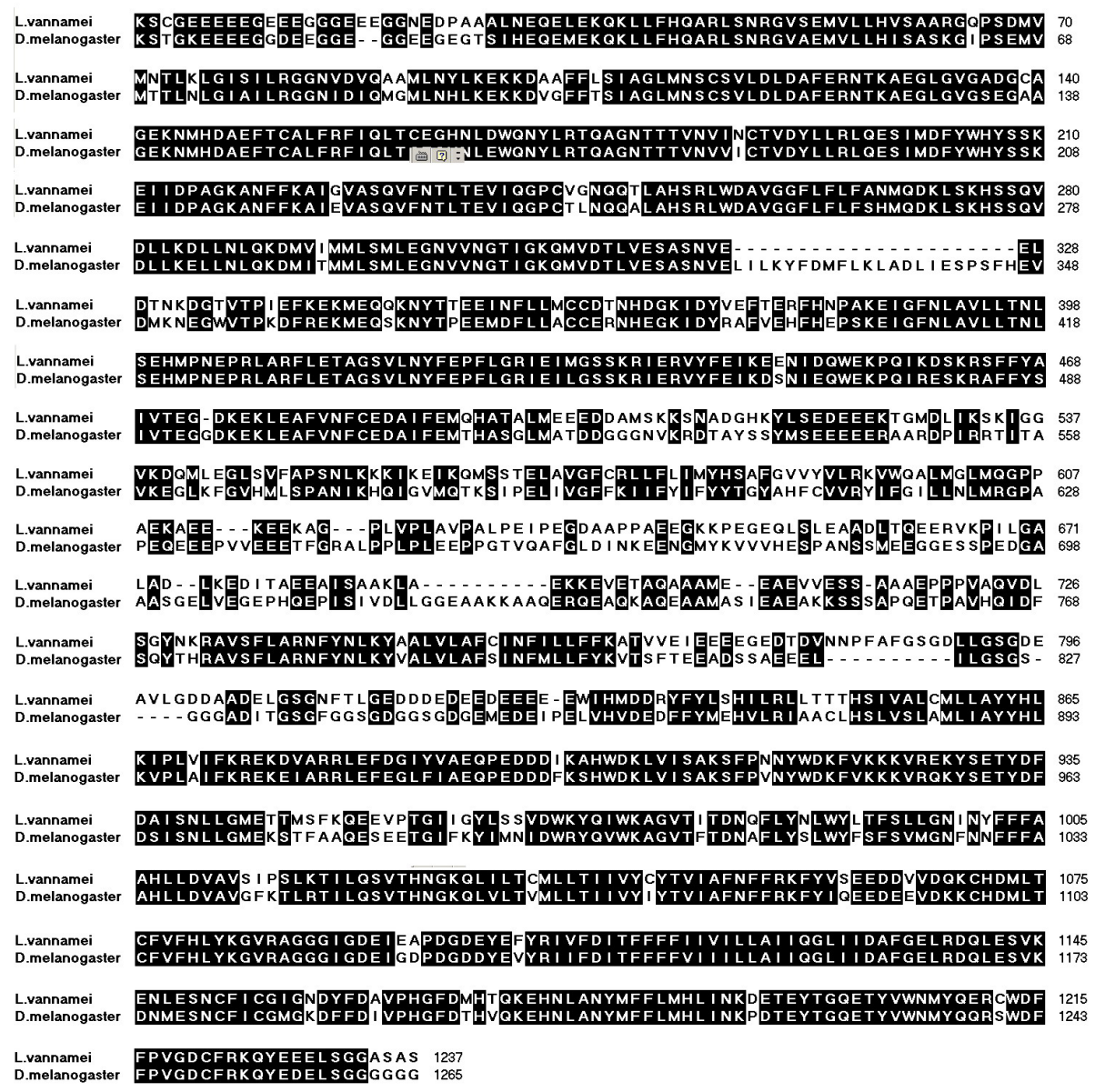

Figure 1. Alignment of the amino acid sequence of ryanodine receptor. The two amino acid sequences, in single letter codes, were deduced from their respective coding sequences. The amino acid sequences of the Litopenaeus vannamei ryanodine receptor gene (upper line) was aligned to that from Drosophila melanogaster ryanodine receptor gene (lower line) (GenBank: NM_057645). Identical amino acid residues among species are presented with a black background. 
Direct sequencing of PCR-amplified (Figure 2) ryanodine receptor exons with their intron-flanking regions from 20 DNA samples, revealed the presence of 7 single-nucleotide polymorphisms (SNPs). Five of them (1713A/G, 1749T/C, 1755T/C, 3965G/A, and 8737C/T) are localized in exons, and appear to be neutral (synonymous) since they do not modify the encoded amino acid. The other SNPs (1553C/T and 13337A/G) are in introns.

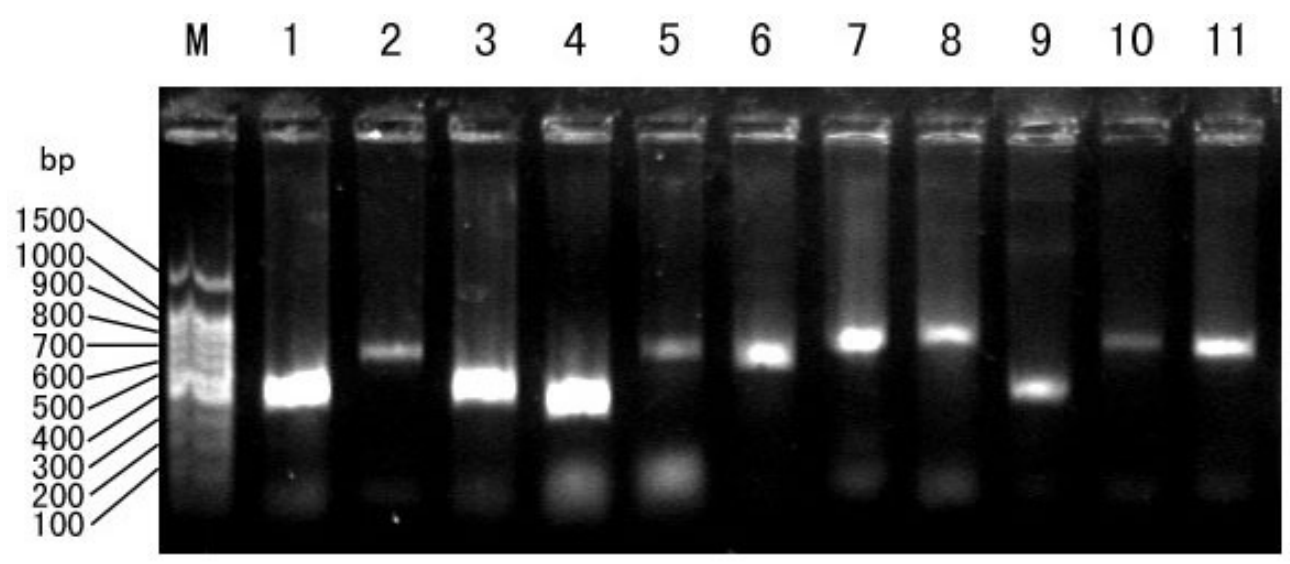

Figure 2. PCR amplification products of the ryanodine receptor genomic DNA using 11 pairs of primers, respectively. $\mathrm{M}=$ a 100-bp DNA ladder marker; lanes $1-11=$ the No. of the primers.

\section{DISCUSSION}

In this study, we had cloned partial ryanodine receptor gene sequence of $L$. vanna$m e i$. To our knowledge, this is the first report to clone the ryanodine receptor of $L$. vannamei. However, the size of ryanodine receptor gene is very large (e.g., the genomic DNA of $D$. melanogaster ryanodine receptor is $\sim 25 \mathrm{~kb}$ ), and the genomic DNA sequence of $L$. vannamei ryanodine receptor is still incomplete. Anyway, this is very helpful in the future cloning of full length sequences of ryanodine receptor gene.

The shrimps with cramped muscle syndrome for SNP detection were characterized by an ante-mortem ventral flexure of the abdomen, which is so rigid that it cannot be straightened without tearing the abdominal muscle tissue. The syndrome was very similar to the cramped muscle syndrome previously reported (Lightner, 1988). However, we had not found the nonsynonymous mutation that may led to the shrimp sensitivity to stress, suggesting that the nonsynonymous mutations (if they exist) may be localized in the remaining regions, which have not been identified in the present study. The SNP identification in ryanodine receptor reported here would be useful in future association studies aimed at determining the physiologic role of ryanodine receptor in stress-sensitivity of shrimp.

\section{ACKNOWLEDGMENTS}

Research supported by the National Natural Science Foundation of China (\#30860214), Guangxi Department of Science (\#0992025-3), and Natural Science Foundation of Guangxi (\#0991106). 


\section{REFERENCES}

Boone L (1931). Anomuran, macruran Crustacea from Panama and Canal Zone. Bull. Am. Mus. Nat. Hist. 63: 137-189.

De-la-Vega E, O'Leary NA, Shockey JE, Robalino J, et al. (2008). Anti-lipopolysaccharide factor in Litopenaeus vannamei (LvALF): a broad spectrum antimicrobial peptide essential for shrimp immunity against bacterial and fungal infection. Mol. Immunol. 45: 1916-1925.

Fujii J, Otsu K, Zorzato F, de Leon S, et al. (1991). Identification of a mutation in porcine ryanodine receptor associated with malignant hyperthermia. Science 253: 448-451.

Higgins DG and Sharp PM (1988). CLUSTAL: a package for performing multiple sequence alignment on a microcomputer. Gene 73: 237-244.

Hoskins RA, Carlson JW, Kennedy C, Acevedo D, et al. (2007). Sequence finishing and mapping of Drosophila melanogaster heterochromatin. Science 316: 1625-1628.

John AC (1992). Pathobiology of Marine and Estuarine Organisms. In: Biology (John AC and John WF, eds.). CRC Press, Boca Raton, 346-349.

Jurkat-Rott K, McCarthy T and Lehmann-Horn F (2000). Genetics and pathogenesis of malignant hyperthermia. Muscle Nerve 23: 4-17.

Lightner DV (1988). Disease Diagnosis and Control in North American Marine Aquaculture. In: Biology (Sindermann CJ and Lightner DV, eds.). Elsevier, Amsterdam, 30-47.

Loke J and MacLennan DH (1998). Malignant hyperthermia and central core disease: disorders of $\mathrm{Ca}^{2+}$ release channels. Am. J. Med. 104: 470-486.

Lorenzon NM and Beam KG (2000). Calcium channelopathies. Kidney Int. 57: 794-802.

Mitchell G and Heffron JJ (1982). Porcine stress syndromes. Adv. Food Res. 28: 167-230.

Sakube Y, Ando H and Kagawa H (1997). An abnormal ketamine response in mutants defective in the ryanodine receptor gene ryr-1 (unc-68) of Caenorhabditis elegans. J. Mol. Biol. 267: 849-864.

Shiwa M, Murayama T and Ogawa Y (2002). Molecular cloning and characterization of ryanodine receptor from unfertilized sea urchin eggs. Am. J. Physiol. Regul. Integr. Comp. Physiol. 282: R727-R737.

Takeshima H, Nishi M, Iwabe N, Miyata T, et al. (1994). Isolation and characterization of a gene for a ryanodine receptor/ calcium release channel in Drosophila melanogaster. FEBS Lett. 337: 81-87.

Valles-Jimenez R, Cruz P and Perez-Enriquez R (2004). Population genetic structure of Pacific white shrimp (Litopenaeus vannamei) from Mexico to Panama: microsatellite DNA variation. Mar. Biotechnol. 6: 475-484.

Zemann A, Op de Bekke A, Kiefmann M, Brosius J, et al. (2006). Evolution of small nucleolar RNAs in nematodes. Nucleic Acids Res. 34: 2676-2685. 